\title{
Genetic stability in synthetic wheat accessions: cytogenetic evaluation as a support in breeding programs
}

\author{
Patrícia Frizon $^{1}$ Sandra Patussi Brammer ${ }^{2 *}$ Maria Imaculada Pontes Moreira Lima $^{2}$ \\ Ricardo Lima de Castro $^{2}$ Carolina Cardoso Deuner ${ }^{1}$
}

\author{
'Universidade de Passo Fundo (UPF), Passo Fundo, RS, Brasil. \\ ${ }^{2}$ Empresa Brasileira de Pesquisa Agropecuária (Embrapa Trigo), Passo Fundo, RS, Brasil. E-mail: sandra.brammer@embrapa.br.
}

ABSTRACT: Synthetic wheat is developed by crossing tetraploid species (Triticum turgidum, AABB) with a diploid species (Aegilops tauschii, $D D$ ), followed by chromosome duplication through the use of colchicine to restore the resultant sterile hybrid to a fertile hexaploid plant. The main importance of producing synthetically improved wheat is to increase their genetic variability and to incorporate genes that code for resistance to biotic and abiotic stressors. This study aimed to evaluate the presence of micronuclei (MN) and the meiotic index (MI) in the tetrad phase in synthetic wheat accessions and cultivars (Triticum aestivum) stored at the Germplasm Bank of Embrapa Trigo (Brazil), in order to identify and select genetically stable accessions for plant improvement. Five plants were collected by genotype, prior to anthesis, and the tissues were fixed in Carnoy solution. Cytological slides were prepared by the smash method, and the cells were dyed with 1\% acetocarmine and observed under an optical microscope. Presence of $M N$ was observed in all genotypes analyzed, and variability of genetic stability was reported in the two years of analysis. In 2014, the highest MI of synthetic wheat accessions was $96.86 \%$ and the lowest was $46.32 \%$. In 2015 , the highest MI was $96.60 \%$ and the lowest was $47.96 \%$. Based on the results, some genotypes were considered meiotically stable and suitable for use in wheat breeding programs.

Key words: Aegilops tauschii, meiotic index, micronuclei.

Estabilidade genética em acessos de trigos sintéticos: avaliação citogenética como apoio em programas de melhoramento genético

\begin{abstract}
RESUMO: Trigos sintéticos são resultados do cruzamento entre uma espécie tetraploide (Triticum turgidum, AABB) e uma espécie diploide (Aegilops tauschii, DD) originando um híbrido estéril, seguido por duplicação cromossômica, por meio de colchicina, para restabelecer um trigo hexaploide fértil. A principal importância do uso de trigos sintéticos no melhoramento é que possibilitam aumentar a variabilidade genética, bem como introgredir genes de resistência a estresses bióticos e abióticos. O presente estudo teve como objetivo avaliar a presença de micronúcleos (MCN) e índice meiótico (IM) na fase de tétrades, em acessos de trigos sintéticos e cultivares testemunhas (T. aestivum), armazenadas no Banco de Germoplasma da Embrapa Trigo, a fim de selecionar os acessos estáveis geneticamente e disponibilizar ao melhoramento. Cinco plantas por genótipos, na fase anterior à antese, foram coletadas e fixadas em solução Carnoy. As lâminas citológicas foram preparadas pelo método de maceração e a coloração das células com carmim acético 1\%. As observações foram em microscópio óptico. Observou-se a presença de micronúcleos em todos os genótipos analisados e foi encontrado variabilidade quanto à estabilidade genética nos dois anos de análises. Em 2014, o percentual máximo de IM dos acessos de trigos sintéticos foi de 96,86\% e o mínimo de 46,32\%. Em 2015, o percentual de IM máximo foi de 96,60\% e o mínimo de 47,96\%. Com base nos resultados, alguns genótipos foram considerados meioticamente estáveis e, poderão ser utilizados em programas de melhoramento genético de trigo.
\end{abstract}

Palavras-chaves: Aegilops tauschii, índice meiótico, micronúcleo.

\section{INTRODUCTION}

Wheat (Triticum aestivum L.) is a staple food grain that will play an increasingly important role as human populations continue to grow. Wheat plant originated millions of years ago from the natural hybridization between two diploid species, Triticum urartu Gandylian and Aegilops speltoides Á. Löve, creating the tetraploid wheat Triticum dicoccoides Schrank. About 10,000 years later, the domestication of this cereal had contributed to the evolution of Triticum durum Desf., which was hybridized with the wild species Aegilops tauschii Coss to produce the hexaploid wheat T. aestivum (AABBDD) (MUJEEB-KAZI et al., 1996). 
Synthetic hexaploid wheat plants are produced by artificial crossbreeding between tetraploid species, such as Triticum turgidum (genome AABB, 2n $=28$ ), and the diploid wild relative Ae. tauschii (genome DD, 2n = 14), and successively undergoing chromosome doubling with colchicine to create a hexaploid genome (AABBDD) (TRETHOWAN \& VAN GINGEL, 2009). The genetic diversity reported in the D genome of Ae. tauschii is much higher than that in the common wheat (REIF et al., 2005; NAGHAVI \& MARDI, 2010).

Cytogenetic studies compare wild and cultivated populations on the basis of their chromosome characteristics during cell division. Regardless of an adequate supply of germplasm, breeding programs required knowledge of the reproductive mode, number of chromosomes, and meiotic behavior within and between compatible species in order to select strains for crossbreeding (MENDES-BONATO et al., 2006). Wild and crossbred plants have variable meiotic behavior among genotypes. As such, genotypes may be anomalous (e.g., produce micronuclei $(\mathrm{MN})$ ) in the meiotic and post-meiotic phases, resulting in limited fertility of the male gametes (DAMASCENO JUNIOR et al., 2010).

Calculation of the meiotic index (MI) is a simple procedure for evaluating the regularity of the meiotic process, and since it is a quick cytological technique, the degree of meiotic stability is readily reported (LOVE, 1951). In this context, this study evaluated the genetic stability of synthetic wheat accessions stored at the Active Germplasm Bank (BAG) of the Empresa Brasileira de Pesquisa Agropecuária (Embrapa Trigo), Passo Fundo, RS, Brazil, by analyzing the $\mathrm{MN}$ and $\mathrm{MI}$, in order to identify superior accessions for use in crossbreeding programs aiming to increase genetic variability and diversity, as well as to introgress genes with resistance to biotic and abiotic stressors.

\section{MATERIALS AND METHODS}

Twenty synthetic wheat accessions from the International Maize and Wheat Improvement Center (CIMMYT, Mexico) were evaluated and stored at the BAG of Embrapa Trigo; namely, CIGM88.1351-OB, CIGM90.896, CIGM90.909, CIGM92.1629, CIGM92.1666, CIGM92.1680, CIGM92.1696, CIGM92.1698, CIGM92.1706, CIGM92.1713, CIGM92.1849, CIGM93.200, CIGM93.205, CIGM93.225, CIGM93.268, CIGM93.294, CIGM93.298, CIGM93.302, CIGM93.403, and CASW94Y00054S. Six traditional varieties of wheat also stored at the BAG were witness cultivars; namely, 'BR 18 Terena', 'BRS Guamirim', 'BRS 194', 'BRS 179', 'Frontana', and 'Sumai 3'. The test was carried out in an experimental field of Embrapa Trigo (latitude $28^{\circ} 15^{\prime} 46^{\prime \prime} \mathrm{S}$, longitude $52^{\circ} 24^{\prime} 24^{\prime \prime} \mathrm{W}$, and altitude $684 \mathrm{~m}$ ) in 2014 and 2015.

Cytogenetic analyses were performed in the Laboratory of Biotechnology, Cytogenetic Department at Embrapa Trigo. The randomized block design included 26 treatments and three replications. Each genotype was sown in a part composed of a 5-m line with 60 suitable seeds per linear meter. The test was carried out according to the wheat and triticale production manual (REUNIÃO, 2014).

Five ears of wheat per genotype (treatment) were randomly collected prior to anthesis. The ears were fixed in Carnoy fixative (absolute ethanol:glacial acetic acid, 3:1), for 24 hours at room temperature, and stored in $70 \%$ ethanol at $-20^{\circ} \mathrm{C}$. Slides were prepared for cytological evaluation using three anthers of a same flower and the medial portion of an ear. The anthers were crushed and stained with $1 \%$ acetocarmine. Variables analyzed were normal tetrads and presence of $\mathrm{MN}$. Each treatment was carried out with five replicates; an ear and a slide represented each repetition. The first 200 entire tetrads were counted and analyzed for the presence or absence of MN. A Zeiss Axio Lab optical microscope ( $\times 400$ magnification) and Pinnacle Studio Plus software were used for the analysis.

The MI was calculated according to LOVE (1949), where MI = (number of normal tetrads/ number of tetrads analyzed) $\times 100$. Cultivars for which the MI was $>90 \%$ were considered meiotically stable. In 2014, the accession CIGM92.1629 was not statistically analyzed for tetrads with $\mathrm{MN}$ and MI, because the tetrad phase was not reported. In 2015, however, this genotype was statistically analyzed. After angular transformation (arcsine square root of the proportion) and checking variance homogeneity with the Cochran test at $1 \%$, statistical analysis was performed using the software Genes (CRUZ, 2013), first by analysis of variance and then with the ScottKnott test at 5\% probability.

\section{RESULTS AND DISCUSSION}

Analysis of variance of the 2014 and 2015 test results showed significant differences between treatments with respect to the presence of $\mathrm{MN}$ and the MI, according to the F-test at a significance level of 5\% (Table 1 and 2). Pearson's product-moment correlation coefficient was also highly significant $(\mathrm{r}=0.52)$. As such, 
Table 1 - Analysis of variance and Pearson correlation coefficients for the presence of micronuclei in 2014 and 2015, Embrapa Trigo, Passo Fundo/RS.

\begin{tabular}{|c|c|c|c|c|c|c|c|c|}
\hline FV & GL & SQ & QM & $\mathrm{F}$ & GL & SQ & QM & $\mathrm{F}$ \\
\hline Treatments & 24 & 420,07017 & 17,5029 & $7.9268^{* *}$ & 251 & 3,9155 & 0,156618 & $12,1147^{* *}$ \\
\hline Residue & 100 & 220,8083 & 2,20808 & & 104 & 1,3445 & 0,012928 & \\
\hline Total & 124 & 640,8785 & & & 129 & 5,2599 & & \\
\hline Mean & & & 2,92808 & & & & 0,33304 & \\
\hline $\mathrm{CV}(\%)$ & & & 50,7486 & & & & 34,1408 & \\
\hline $\mathrm{r}=0.52$ & & & & & & & & \\
\hline
\end{tabular}

$\mathrm{r}=$ correlation coefficient of Pearson at $5 \%$ probability.

the magnitude of the correlation coefficient may indicate the importance of the genotype-environment interaction effect, taking into account differences in environmental conditions between years (interaction effect year versus genotype). It is noteworthy to point out the genotypes that outperformed in both years of evaluation.

In 2014, the variable grain with $\mathrm{MN}$ formed three statistically different groups (Table $3)$. Twenty-one wheat genotypes showed tetrads with $<20 \% \mathrm{MN}$ (group C). Two synthetic wheat accessions showed between $30 \%$ and $40 \% \mathrm{MN}$ (group B), and another two accessions had between $50 \%$ and $55 \%$ (group A). The MI of 21 genotypes, including witness cultivars and synthetic wheat accessions, showed a percentage of $>80 \%$ (group A). However, only two accessions had a MI of $<70 \%$ in group B, and two accessions had a MI of $<50 \%$ in group $\mathrm{C}$.
In 2015, the variability in the $\mathrm{MN}$ and $\mathrm{MI}$ percentages of tetrads was higher. With regard to the MN percentages, four groups were distinct. The first group (group A) had genotypes with $>40 \% \mathrm{MN}$; the second group (group B) had genotypes with between $25 \%$ and $31 \% \mathrm{MN}$; and the third group (group C) had genotypes with between $10 \%$ and $25 \% \mathrm{MN}$ (Table 4). Genotypes with minor abnormalities below these values were grouped into group D. For the MI, 15 accessions had a value $>90 \%$ (including six cultivars from group A), seven accessions had a value between $89 \%$ and $75 \%$ (Group B), two accessions had a value between $75 \%$ and $70 \%$ (Group C), and two accessions had values of $<60 \%$.

In 2014 and 2015, six witness cultivars were in the group with superior MI values. However, synthetic wheat accessions with higher MI had different MI values. In 2014, accession

Table 2 - Analysis of variance and Pearson correlation coefficients for meiotic index in 2014 and 2015, EmbrapaTrigo, Passo Fundo/RS.

\begin{tabular}{|c|c|c|c|c|c|c|c|c|}
\hline FV & GL & SQ & QM & $\mathrm{F}$ & GL & SQ & QM & $\mathrm{F}$ \\
\hline Treatments & 24 & 5,3647 & 0,223531 & $9,0918^{* *}$ & 251 & 3,9154 & 0,156615 & $12,1163^{* *}$ \\
\hline Residue & 100 & 2,4586 & 0,024586 & & 104 & 1,3443 & 0,012926 & \\
\hline Total & 124 & 7,8233 & & & 129 & 5,2597 & & \\
\hline Mean & & & 1,2595 & & & & 1,2378 & \\
\hline CV (\%) & & & 12,4496 & & & & 9,1854 & \\
\hline $\mathrm{r}=0.52$ & & & & & & & & \\
\hline
\end{tabular}

$\mathrm{r}=$ correlation coefficient of Pearson at $5 \%$ probability. 
Table 3 - Cytogenetic evaluation in accessions of synthetic wheats and control cultivars: percentage of tetrad with micronucleus (MN) and meiotic index (IM) in 2014, Embrapa Trigo, Passo Fundo/RS.

\begin{tabular}{|c|c|c|c|c|c|}
\hline Genotype & $\mathrm{MN}$ & Group & Genotype & IM & Group \\
\hline CIGM92.1706 & 55,46 & a & BRS 179 & 98,98 & $\mathrm{a}$ \\
\hline CIGM93.268 & 53,68 & $\mathrm{a}$ & BRS Guamirim & 97,96 & $\mathrm{a}$ \\
\hline CIGM93.205 & 38,10 & $\mathrm{~b}$ & Sumai 3 & 97,58 & $\mathrm{a}$ \\
\hline CIGM92.1680 & 30,20 & $\mathrm{~b}$ & CIGM93.403 & 96,86 & $\mathrm{a}$ \\
\hline CIGM90.896 & 19,20 & $\mathrm{c}$ & CIGM92.1666 & 96,68 & a \\
\hline CIGM93.294 & 18,96 & $\mathrm{c}$ & Trigo BR 18 & 96,56 & $\mathrm{a}$ \\
\hline CIGM93.302 & 13,44 & $\mathrm{c}$ & CIGM93.298 & 96,34 & $\mathrm{a}$ \\
\hline CIGM90.909 & 12,96 & $\mathrm{c}$ & CASW94Y00054S & 96,12 & $\mathrm{a}$ \\
\hline CIGM93.200 & 11,56 & $\mathrm{c}$ & BRS 194 & 94,70 & $\mathrm{a}$ \\
\hline CIGM93.225 & 10,50 & $\mathrm{c}$ & CIGM92.1696 & 94,08 & $\mathrm{a}$ \\
\hline Frontana & 10,28 & $\mathrm{c}$ & CIGM88.1351-OB & 92,82 & $\mathrm{a}$ \\
\hline CIGM92.1849 & 09,36 & $\mathrm{c}$ & CIGM92.1698 & 91,80 & $\mathrm{a}$ \\
\hline CIGM92.1713 & 09,28 & $\mathrm{c}$ & CIGM92.1713 & 90,72 & $\mathrm{a}$ \\
\hline CIGM92.1698 & 08,20 & $\mathrm{c}$ & CIGM92.1849 & 90,64 & a \\
\hline CIGM88.1351-OB & 07,18 & $\mathrm{c}$ & Frontana & 89,72 & a \\
\hline CIGM92.1696 & 05,92 & $\mathrm{c}$ & CIGM93.225 & 89,50 & a \\
\hline BRS 194 & 05,30 & $\mathrm{c}$ & CIGM93.200 & 88,44 & $\mathrm{a}$ \\
\hline CASW94Y00054S & 03,88 & $\mathrm{c}$ & CIGM90.909 & 87,04 & $\mathrm{a}$ \\
\hline CIGM93.298 & 03,66 & $\mathrm{c}$ & CIGM93.302 & 86,56 & $\mathrm{a}$ \\
\hline Trigo BR 18 & 03,44 & $\mathrm{c}$ & CIGM93.294 & 81,04 & $\mathrm{a}$ \\
\hline CIGM92.1666 & 03,32 & $\mathrm{c}$ & CIGM90.896 & 80,80 & $\mathrm{a}$ \\
\hline CIGM93.403 & 03,14 & $\mathrm{c}$ & CIGM92.1680 & 69,82 & $\mathrm{~b}$ \\
\hline Sumai 3 & 02,42 & $\mathrm{c}$ & CIGM93.205 & 61,90 & $\mathrm{~b}$ \\
\hline BRS Guamirim & 02,04 & $\mathrm{c}$ & CIGM93.268 & 46,32 & $\mathrm{c}$ \\
\hline BRS 179 & 01,02 & $\mathrm{c}$ & CIGM92.1706 & 44,54 & $\mathrm{c}$ \\
\hline
\end{tabular}

Averages followed by the same letter do not differ statistically by the Scott and knott test at $5 \%$ probability.

CIGM93.403 had a MI of $96.86 \%$, and in 2015 accession CIGM93.294 had a MI of $96.60 \%$. This study found $\mathrm{MN}$ in all the genotypes. In a study with synthetic wheat accessions, MN were the major abnormality reported in dyad and tetrad genotypes (REZAEI et al., 2010).

MN may be defined as structures resulting from entire chromosomes or chromosome fragmentation that are lost in cell division, and; therefore, are not included in the nuclei of daughter cells, remaining in the cytoplasm of interphase cells (HEDDLE, 1973). During telophase, the nuclear envelope is formed around the entire chromosome or missing chromosome, which decondenses and gradually takes on the morphology of the interphase nucleus, except for size (since it is much smaller than its core, hence the name "micronucleus") (FENECH, 2000). These abnormalities in hexaploid synthetic wheat species, which undergone high genotypeenvironment interactions (REZAEI et al., 2010).
Cytomixis, which is the migration of genetic material, gene products, and organelles among meiocytes through cytoplasmic connections or cytomictic channels (FALISTOCCO et al., 1995), may cause $\mathrm{MN}$ formation, especially when associated with prophase (BOLDRINI, PAGLIARINI\& VALLE, 2006).

A possible explanation for the high rates of $\mathrm{MN}$ in synthetic wheat is; however, because this germplasm results from artificial hybridization. In addition, the synthetic wheat genome is a combination of T. turgidum $\times$ Ae. tauschii (REZAEI et al., 2010), causing the meiotic cycle to vary in different genomes, which may cause meiotic instability (OETTLER, 2005).

In addition to these genetic reasons, abiotic factors may also cause the fragmentation of the genetic material, producing cells with MN (DIEGUES et al., 2015). Although cellular repair mechanisms are efficient, $\mathrm{MN}$ formation is due to chromosomal 
Table 4 - Cytogenetic evaluation in accessions of synthetic wheats and control cultivars: percentage of tetrad with micronucleus (MCN) and meiotic index (IM) in the year 2015, Embrapa Trigo, Passo Fundo/RS.

\begin{tabular}{|c|c|c|c|c|c|}
\hline Genotype & $\mathrm{MN}$ & & Genotype & MI & \\
\hline CIGM90.896 & 52,04 & $\mathrm{a}$ & BRS 179 & 99,54 & $\mathrm{a}$ \\
\hline CIGM92.1629 & 43,62 & $\mathrm{a}$ & Trigo BR 18 & 97,06 & $\mathrm{a}$ \\
\hline CIGM93.268 & 30,38 & $\mathrm{~b}$ & CIGM93.294 & 96,60 & $\mathrm{a}$ \\
\hline CIGM93.205 & 26,94 & $\mathrm{~b}$ & Frontana & 96,20 & $\mathrm{a}$ \\
\hline CIGM92.1696 & 22,50 & $\mathrm{c}$ & BRS Guamirim & 96,08 & $\mathrm{a}$ \\
\hline CIGM92.1680 & 16,66 & $\mathrm{c}$ & CIGM93.302 & 95,84 & $\mathrm{a}$ \\
\hline CIGM88.1351-OB & 15,42 & $\mathrm{c}$ & CIGM92.1713 & 95,30 & a \\
\hline CIGM92.1698 & 14,58 & $\mathrm{c}$ & CASW94Y00054S & 92,50 & $\mathrm{a}$ \\
\hline CIGM90.909 & 14,08 & $\mathrm{c}$ & CIGM92.1849 & 92,50 & $\mathrm{a}$ \\
\hline CIGM92.1706 & 12,74 & $\mathrm{c}$ & BRS 194 & 92,04 & $\mathrm{a}$ \\
\hline CIGM93.298 & 11,58 & $\mathrm{c}$ & CIGM92.1666 & 91,56 & $\mathrm{a}$ \\
\hline Sumai 3 & 09,36 & $\mathrm{~d}$ & CIGM93.200 & 91,14 & a \\
\hline CIGM93.225 & 09,02 & $\mathrm{~d}$ & CIGM93.403 & 91,12 & a \\
\hline CIGM93.403 & 08,88 & $\mathrm{~d}$ & CIGM93.225 & 90,98 & $\mathrm{a}$ \\
\hline CIGM93.200 & 08,86 & d & Sumai 3 & 90,64 & a \\
\hline CIGM92.1666 & 08,44 & $\mathrm{~d}$ & CIGM93.298 & 88,42 & $\mathrm{~b}$ \\
\hline BRS 194 & 07,96 & $\mathrm{~d}$ & CIGM92.1706 & 87,26 & $\mathrm{~b}$ \\
\hline CIGM92.1849 & 07,50 & $\mathrm{~d}$ & CIGM90.909 & 85,92 & $\mathrm{~b}$ \\
\hline CASW94Y00054S & 07,50 & $\mathrm{~d}$ & CIGM92.1698 & 85,42 & $\mathrm{~b}$ \\
\hline CIGM92.1713 & 4,70 & $\mathrm{~d}$ & CIGM88.1351-OB & 84,58 & $\mathrm{~b}$ \\
\hline CIGM93.302 & 4,16 & $\mathrm{~d}$ & CIGM92.1680 & 83,34 & $\mathrm{~b}$ \\
\hline BRS Guamirim & 3,92 & $\mathrm{~d}$ & CIGM92.1696 & 77,50 & $\mathrm{~b}$ \\
\hline Frontana & 3,80 & $\mathrm{~d}$ & CIGM93.205 & 73,06 & $\mathrm{c}$ \\
\hline CIGM93.294 & 3,40 & $\mathrm{~d}$ & CIGM93.268 & 69,62 & $\mathrm{c}$ \\
\hline BR 18 Terena & 2,94 & $\mathrm{~d}$ & CIGM92.1629 & 56,38 & d \\
\hline BRS 179 & 0,46 & $\mathrm{~d}$ & CIGM90.896 & 47,96 & d \\
\hline
\end{tabular}

Averages followed by the same letter do not differ statistically by the Scott and knott test at 5\% probability.

abnormalities, often related to environmental factors (MAJER et al., 2001).

In 2014, for example, a synthetic wheat accession with higher MN percentage was CIGM92.1706 (55.46\%), which was collected for tetrad analysis in the second half of October, when the minimum and maximum temperatures and relative humidity were above normal. Likewise, in 2015, synthetic wheat accessions with a higher MN percentage (group A) were those undergoing the tetrad phase at the end of October, when the average minimum and maximum temperatures and relative humidity were again above normal. The relative humidity was $9.6 \%$ above normal for that month.

Relative humidity variations may affect MN formation in the tetrad phase (SPÓSITO et al., 2015). In a study with wheat, OMIDI et al. (2014) noted that varieties had the lowest amounts of abnormalities in normal environmental conditions.
Several varieties had significant increases in meiotic changes as the temperature increased.

Accessions with a high incidence of $\mathrm{MN}$ are not recommended for use in crossbreeding, since the material contained in these MN may ultimately influence gene expression in nuclear ribosomal DNA, mitochondrial DNA, and chloroplast DNA. This fact may also cause very important evolutionary implications, alter the variability of produced meiospores, and have an effect on the viability and ploidy level of pollen grains (DIEGUES et al., 2015). In this study, the MN percentage in group $C$ averaged $7.86 \%$, the lowest in 2014. In 2015, group $\mathrm{D}$ had an average of $6.06 \% \mathrm{MN}$. Other MN patterns, lower than those reported in this study, have already been found in synthetic wheat accessions. This may be a further indication of environmental influences, since the characteristics of the evaluated sites differed greatly. 
With regard to the MI, 15 out of the 19 synthetic wheat accessions were in group $\mathrm{A}$, which was the group with superior MI percentages in 2014 (average 90.63\%). Four genotypes were in the second and third groups (B and $\mathrm{C}$ ), with an average $\mathrm{MI}$ of $<70 \%$. In 2015, nine synthetic wheat accessions in group A had an average MI of $93.13 \%$. Seven accessions in group B had an average MI of $84.63 \%$. Four synthetic accessions of the remaining two groups had an average MI of $<72.5 \%$. Genotypes with a MI of $<90 \%$ may result in reproductive issues when involved in crossbreeding, because they are considered cytogenetically unstable, and this may ultimately make chromosome pairing difficult (LOVE, 1951).

Both in 2014 and 2015, the wheat cultivar 'BRS 179' had maximum MI and minimum MN percentages. The average MI in cultivars was $95.91 \%$ and $95.26 \%$ in 2014 and 2015, respectively, both in group A. Comparatively, studies with species of the Caricaceae family had higher MI percentages in cultivated than in wild species (DAMASCENO JUNIOR et al., 2010). The MI of 19 genotypes of synthetic wheat accessions ranged from $44.54 \%$ to $96.86 \%$ in 2014 . In 2015 , the maximum and minimum MI of synthetic wheat was $96.60 \%$ and $47.96 \%$, respectively. In both years, variability of the genetic stability of the wheat products was noted. In an Iranian study with synthetic wheat accessions, the lowest MI was 99\% (ARABBEIGI et al., 2010).

When interspecific hybrids are the object of study, such as synthetic wheat, it is essential to know the meiotic behavior of the species before using them in crossbreeding. The meiotic behavior in plants is related to their degree of fertility, and formation of functional gametes is controlled by genes that guarantee a normal meiotic process (PAGLIARINI, 2000). The identification of more stable genotypes using cytological analysis; therefore, permits both the planning of seed production of cultivars to be launched, and support their potential use to produce new wheat populations (POZZOBON et al., 2011).

\section{CONCLUSION}

This study found variability (due to genetic and environmental factors) in the genetic stability of synthetic wheat accessions in both years that the experiment was carried out. Thus, only meiotically stable genotypes should be incorporated in crossbreeding studies involving hybridization, with the aim to increase the genetic variability of wheat plants and introgression of genes with resistance to biotic and abiotic stressors.

\section{ACKNOWLEDGEMENTS}

Universidade de Passo Fundo (UPF), Fundação de Amparo à Pesquisa do Estado do Rio Grande do Sul (FAPERGS), Empresa Brasileira de Pesquisa Agropecuária (EMBRAPA TRIGO).

\section{REFERENCES}

ARABBEIGI, M. et al. Meiotic behavior of wild, synthetic and cultivated wheats. Cytologia, Tokyo, v. 75, p. 169-175, 2010. Available from: <https://www.jstage.jst.go.jp/article/ cytologia/75/2/75_2 169/_pdf>. Accessed: Jan. 12, 2016. doi: 10.1508/cytologia. $\overline{7}$. 169 .

BOLDRINI, K. R. et al. Cell fusion and cytomixis during microsporogenesis in Brachiaria humidicola (Poaceae). South African Journal of Botany, Scottsville, v. 72, p. 478-481, 2006. Available from: <http://ac.els-cdn.com/S025462990600038X/1-s2.0S025462990600038X-main.pdf?_tid=f26caf5e-eb79-11e5b454000 00aab0f01\&acdnat=1458134649_129739d109a99edb603d1fca47 8c2497>. Accessed: Nov. 15, 2015. doi: 10.1016/j.sajb.2005.11.004.

CRUZ, C. D. GENES - a software package for analysis in experimental statistics and quantitative genetics. Acta Scientiarum, Maringá, v. 35, p. 271-276, 2013. Available from: $<$ http://periodicos.uem.br/ojs/index.php/ActaSciAgron/article/ view/21251/pdf 1>. Accessed: Oct. 12, 2015. doi: 10.4025/ actasciagron.v3 $\overline{5} \mathrm{i} 3.21251$.

DAMASCENO JUNIOR, P. C et al. Meiotic behavior of Carica papaya and Vasconcelle amonoica. Caryologia, Firenze, v. 63, p. 229-236, 2010. Available from: <http://www.tandfonline.com/ doi/s/10.1080/00087114.2010.10589732\#aHR0cDovL3d3dy50Y W5kZm9ubGluZS5jb20vZG9pL3BkZi8xMC4xMDgwLzAwMD g3MTE0LjIwMTAuMTA1ODk3MzJAQEAw>. Accessed: Sept. 14, 2015. doi: 10.1080/00087114.2010.10589732.

DIEGUES, P. I. et al. Meiotic behavior and pollen viability in the species Jatropha curcas L. Ciências Agrárias, Londrina, v. 36, p. 141-150, 2015. Available from: <http://www.uel.br/revistas/uel/ index.php/semagrarias/article/view/14926/16036>. Accessed: Oct. 17, 2015. doi: 10.5433/1679-0359.2015v36n1p141.

FALISTOCCO, E.et al. Cytomixis in pollen mother cells of diploid Dactylis, one of origins of $2 \mathrm{n}$ gametes. Journal of Heredity, Washington, v. 86, n. 6, p. 448-453, 1995.

FENECH, M. The in vitro micronucleus technique. Mutation Research, Amsterdan, v. 455, p. 81-95, 2000. Available from: $<$ http:// ac.els-cdn.com/S0027510700000658/1-s2.0-S0027510700000658main.pdf? tid=3acd9d06-eb7c-11 e5-896500000aacb35e\&acdn at $=1458135630 \_$cb3a7cbb2adfcae4030dc024f7af08f0>. Accessed: Nov. 18, 2015. doi: 10.1016/S0027-5107(00)00065-8.

HEDDLE, J. A. A rapid in vitro test for chromosomal damage. Mutation Research, Amsterdam, v. 18, n. 2, p. 187-190, 1973. Available from: <http://ac.els-cdn.com/0027510773900353/1s2.0-0027510773900353-main.pdf?_tid=a6b678f8-eb7c-11e5a01c-00000aacb35f\&acdnat $=1458135811 \_0 \mathrm{cdaf} 8406 \mathrm{ffac} 2239 \mathrm{f}$ a62b20d7972bdc $>$. Accessed: Nov. 22,2015. doi: 10.1016/00275107(73)90035-3.

LOVE, R. M. Varietal differences in meiotic chromosomes behavior of Brazilian wheats. Agronomy Journal, Madison, v. 43, n. 2, p. 72-76, 1951. 
MAJER, B. J. et al. Use of the micronucleus assay with exfoliated epithelial cells as a biomarker for monitoring individuals at elevated risk of genetic damage and in chemoprevention Trials. Mutation Research, Amsterdam, v. 489, p. 147-172, 2001 Available from: <http://ac.els-cdn.com/S1383574201000680/1s2.0-S1383574201000680-main.pdf?_tid=38f4fe0a-eb7e-11e5bd3800000aacb35d\&acdnat $=1458136485 \_4963 \mathrm{~b} 0 \mathrm{e} 96 \mathrm{~d} 72 \mathrm{fd} 1$ d5cca4f037ce017dc>. Accessed: Nov. 21, 2015. doi: 10.1016/ S1383-5742(01)00068-0.

MENDES-BONATO, A. B. et al. Chromosome number and meiotic behavior in Brachiaria jubata (Gramineae). Journal of Genetics, Bengaluru, v. 85, p. 83-87, 2006. Available from: <file://C:/Users/ citogenetica/Downloads/83\%20(1).pdf>. Accessed: Nov. 18, 2015. doi: 10.1007/BF02728976.

MUJEEB-KAZI, A. et al. Conservation of the genetic variation of Triticum tauschii in synthetic hexaploid wheats and its potential utilization for wheat improvement. Genetic Resources and Crop Evolution, Dordrecht, v. 43, p. 129-134, 1996. Available from: $<$ https://link.springer.com/article/10.1007\%2FBF00126756\#pa ge-1>. Accessed: Nov. 25, 2015. doi: 10.1007/BF00126756.

NAGHAVI, M. R.; MARDI, M. Characterization of genetic variation among accessions of Aegilops tauschii. Journal of Molecular Microbiology and Biotechnology, Switzerland, v. 18, p. 93-96, 2010. Available from: <http://www.msmbb.org. my/apjmbb/html181/181u.pdf>. Accessed: Nov. 29, 2015. doi: $10.1270 /$ jsbbs.61.347.

OETTLER, G. The fortune of a botanical curiosity triticale: past present and future. Journal of Agricultural Science, Toronto, v. 143, p. 329-346, 2005. Available from: $<$ https://www.researchgate. net/publication/231847496_The_fortune_of_a_botanical curiosity Triticale Past present and future>. Accessed: Jan. $1 \overline{2}$ 2016. doi: $0.1017 / \overline{\mathrm{S}} 00218596050052 \overline{9} 0$.

OMIDI, M. et al. The influence of terminal heat stress on meiosis abnormalities in pollen mother cells of wheat. Cytologia, Tokyo, $\mathrm{v}$. 79, p. 49-58, 2014. Available from: <https://www.researchgate.net/ publication/289537748_The_Influence_of_Terminal_Heat_Stress
on_Meiosis_Abnormalities_in_Pollen_Mother_Cells_of_Wheat>. Accessed: Dec. 18, 2015. doi: $10.13140 / \mathrm{RG} \cdot 2 \cdot 1.2721 .288 \overline{7}$.

PAGLIARINI, M.Q.S. Meiotic behavior of economically important plant species: the relationship between fertility and male sterility. Genetics and Molecular Biology, Ribeirão Preto, v. 23, n. 4, p. 997-1002, 2000. Available from: <http://www.scielo.br/pdf/gmb/ v23n4/6262.pdf>. Accessed: Nov. 03, 2015. doi: 10.1590/S141547572000000400045

POZZOBON, M. T. et al. Meiosis and pollen viability in advanced pepper strains. Horticultura Brasileira, Brasília, v. 29, p. 212 216, 2011. Available from: <http://www.scielo.br/pdf/hb/v29n2/ a13v29n2.pdf>. Accessed: Oct. 23, 2015.

REIF, J. C. et al. Wheat genetic diversity trends during domestication and breeding. Journal Theoretical and Applied Genetics, Warsaw, v. 110, p. 859-864, 2005. Available from: <https://link. springer.com/article/10.1007\%2Fs00122-004-1881-8\#/page-1>. Accessed: Oct. 25, 2015. doi: 10.1007/s00122-004-1881-8.

REZAEI, M. et al. Meiotic behaviour of tetraploid wheats (Triticum turgidum L.) and their synthetic hexaploid wheat derivates influenced by meiotic restitution and heat stress. Journal of Genetics, Bengaluru, v. 89, p. 401-407, 2010. Available from: <https://link.springer.com/article/10.1007\%2 Fs12041-010-0058-2\#/page-1>. Accessed: Nov. 12, 2015. doi: 10.1007/s12041-010-0058-2.

SPÓSITO, J. C. V. et al. Genetic instability in plants associated with vehicular traffic and climatic variables. Ecotoxicology and Environmental Safety, v. 120, p. 445-448, 2015. Available from: <http://ac.els-cdn.com/S0147651315300014/1s2.0-S0147651315300014-main.pdf?_tid=dc73ba44eb83-11 e5-95b400000a acb361\&acdnat $=1458138907$ b4d62e407cce0b363494e85bbab52ed0>. Accessed: Nov. 17, 2015. doi: 10.1016/j.ecoenv.2015.06.031.

TRETHOWAN, R.M.; VAN GINKEL, M. Synthetic wheat - an emerging genetic resource. In: CARVER, B. Wheat - Science and trade. Ames: John Wiley \& Sons. 2009. p.369-386. 